\title{
Pengaruh Mekanisme Tata Kelola Perusahaan dan Kinerja Keuangan Terhadap Kemungkinan Kebangkrutan pada Perusahaan Manufaktur Sub Sektor Makanan dan Minuman Yang Terdaftar di Bursa Efek Indonesia
}

\author{
Genna Surayal dan Khairina Natsir \\ Program Studi Manajemen Fakultas Ekonomi \& Bisnis \\ Universitas Tarumanagara \\ Email: gennasurayal27@gmail.com
}

\begin{abstract}
This study examines the impact of Corporate Governance Mechanism and Financial Performance to the possible of bankruptcy. The type of research that is used is causal research - a research that is done to find a definitive causal relationship or to find the cause of one or more problems. This study is consisted by three independent variables and one dependent variables which the independent variables being managerial ownership and the proportion of independent board of commissioner and liquidity, with possible of bankruptcy as the dependent variable. The sample in this study are 17 manufacturing company sub sector food and beverage which listed on the Indonesia Stock Exchange from 2014 until 2018 who selected through purposive sampling method. The result of this study are managerial ownership has no significant effect on possible bankruptcy, proportion of independent board commissioner has a significant positive effect on possible bankruptcy, and liquidity has no significant effect on possible bankruptcy.
\end{abstract}

Keywords: managerial ownership, proportion of independent board commissioner, liquidity, and possible of bankruptcy.

Abstrak: Penelitian ini bertujuan untuk menganalisis pengaruh Mekanisme Tata Kelola Perusahaan dan Kinerja Keuangan terhadap Kemungkinan Kebangkrutan. Tipe penelitian yang digunakan merupakan penelitian kausal - penelitian yang dilakukan untuk menemukan hubungan sebab dan akibat yang definitif atau menemukan penyebab dari satu atau lebih masalah. Penelitian ini terdiri dari tiga variabel independen dan satu variabel dependen, yaitu kepemilikan manajerial, proporsi dewan komisaris independen, dan likuiditas sebagai variabel independen, dengan kemungkinan kebangkrutan sebagai variabel dependen. Sampel dari penelitian ini adalah 17 perusahaan manufaktur sub sektor makanan dan minuman yang terdaftar di Bursa Efek Indonesia dari 2014 hingga 2018 yang ditentukan menggunakan metode purposive sampling. Hasil dari penelitian ini adalah kepemilikan manajerial tidak berpengaruh secara signifikan terhadap kemungkinan kebangkrutan, proporsi dewan komisaris independen memiliki pengaruh positif yang signifikan terhadap kemungkinan kebangkrutan, dan likuiditas tidak berpengaruh secara signifikan terhadap kemungkinan kebangkrutan.

Kata kunci: kepemilikan manajerial, proporsi dewan komisaris independen, likuiditas, dan kemungkinan kebangkrutan.

\section{LATAR BELAKANG}

Seiring dengan adanya perkembangan dalam peradaban manusia maupun ilmu pengetahuan dan teknologi, globalisasi menjadi suatu era yang sudah tidak dapat dihindari. 
Kita harus bisa menghadapinya dengan saksama serta turut berperan di dalam setiap tantangan maupun peluang yang ada. Maka dari itu, demi menjadi yang terbaik, sebuah unit bisnis harus mampu dalam menerapkan proses bisnis yang lebih efektif dan juga efisien. Munculnya unit-unit bisnis yang baru tentunya akan memicu suatu persaingan bisnis yang semakin kuat dari waktu ke waktu.

Salah satu cara untuk mengetahui kondisi atau keadaan perusahaan di tengah era perkembangan globalisasi adalah dengan melihat bagaimana pelaporan hasil kerja perusahaan yang tertera di dalam laporan keuangan perusahaan. Kondisi perusahaan yang cenderung berubah dalam jangka waktu tertentu tentu saja harus dilaporkan kepada siapa saja yang menjadi pemangku kepentingan (stakeholder) dari perusahaan yang bersangkutan. Laporan keuangan berisikan mengenai informasi-informasi posisi dan kinerja keuangan yang menghubungkan perusahaan dengan para pemangku kepentingan. Dengan melihat laporan keuangan, tentunya para pemangku kepentingan dapat menentukan keputusan seperti apa yang akan diambil untuk ke depannya. Semua informasi data yang tertera pada laporan keuangan sangat bermanfaat untuk melihat bagaimana kondisi keuangan dari perusahaan itu sendiri. Kesulitan yang terjadi pada perusahaan dan tanda-tanda yang mengarah pada kebangkrutan dapat diketahui dengan melakukan analisis terhadap data yang tertera pada laporan keuangan perusahaan yang bersangkutan. Tentunya kebangkrutan bukan merupakan hal yang baik dan sama sekali tidak diinginkan oleh semua pihak karena dapat mendatangkan kerugian. Maka dari itu, ada banyak penelitian yang dilakukan guna memprediksi bagaimana kelangsungan hidup dari sebuah perusahaan.

Pada mulanya ketertarikan akan tata kelola perusahaan di Indonesia dimulai semenjak terjadinya krisis ekonomi yang menimpa kawasan Asia khususnya Indonesia pada tahun 1998. Terjadinya peristiwa tersebut memperburuk kondisi keuangan negara Indonesia serta tentunya berimbas pada perekonomian yang semakin melemah (Ramadhani dan Lukviarman, 2009). Berdasarkan data yang ada, krisis ekonomi yang terjadi pada tahun 1998 merupakan krisis ekonomi terparah yang pernah melanda dalam sejarah perekonomian Indonesia. Salah satu faktor yang menjadi penyebab terjadinya krisis ekonomi di Indonesia adalah kurangnya tata kelola yang melandasinya. Sehingga dengan terjadinya hal ini pemerintah mulai melirik untuk memberlakukan corporate governance untuk memperbaiki keadaan akibat krisis yang melanda. Mulai saat itu, pihak pemerintah maupun investor mulai menaruh perhatian lebih pada praktik tata kelola perusahaan atau corporate governance. Mekanisme tata kelola perusahaan ini pada akhirnya juga banyak diterapkan dalam pengelolaan perusahaan. Struktur tata kelola yang baik di dalam sebuah perusahaan tentunya memiliki dampak yang signifikan terhadap keberhasilan perusahaan. Dengan adanya struktur tata kelola yang semakin baik, diharapkan akan membawa perusahaan kepada kemungkinan kebangkrutan yang rendah.

\section{KAJIAN TEORI}

Kepemilikan Manajerial. Yuli Soesetio (2007) mendefinisikan kepemilikan manajerial sebagai perbandingan antara kepemilikan saham manajerial dengan jumlah saham yang beredar. Pemegang saham dan manajer masing-masing memiliki kepentingan dalam memaksimalkan tujuannya. Wahidahwati (2002:5) dalam Rustendi dan Jimmi (2008) menyatakan bahwa kepemilikan manajerial merupakan pemegang saham dari pihak perusahaan yang secara langsung ikut ambil bagian dalam proses penentuan keputusan dalam perusahaan. Kepemilikan manajerial diukur berdasarkan jumlah presentase saham yang dimiliki oleh pemegang saham itu sendiri. Menurut Tjeleni (2013), kepemilikan saham merupakan keadaan dimana manajer perusahaan mempunyai saham di dalam perusahaan atau dengan kata lain manajer tersebut juga berperan sebagai pemegang saham. Berdasarkan definisi yang telah dikemukakan oleh para ahli sebelumnya mengenai kepemilikan 
manajerial, maka dapat disimpulkan bahwa kepemilikan manajerial merupakan kepemilikan saham yang dimiliki oleh pihak manajemen sehingga membuatnya memiliki peran ganda di dalam perusahaan serta ikut dalam proses pengambilan keputusan.

Proporsi Dewan Komisaris Independen. Menurut Agoes dan Ardana (2014:110), komisaris independen merupakan seseorang yang ditugaskan untuk mewakilkan para pemegang saham independen (minoritas), dimana yang menjadi dewan komisaris independen dipilih berdasarkan latar belakang pengetahuan yang mencukupi, pengalaman, serta keahlian profesional yang dimiliki guna menjalankan tugas demi tujuan dan kepentingan perusahaan. Menurut Komite Nasional Kebijakan Governance (2006), komisaris independen merupakan anggota dewan komisaris yang tidak berhubungan dengan pihak manajemen, dewan komisaris lainnya, dan para pemegang saham pengendali (mayoritas). Dewan komisaris independen juga terbebas akan hubungan bisnis dan hubungan lainnya yang dapat memberi pengaruh terhadap kemampuannya dalam berlaku independen atau berlaku semata-mata demi kepentingan perusahaan. Fama dan Jensen (dalam Ujiyantho dan Pramuka, 2007) menyatakan bahwa anggota dewan komisaris independen (non-executive director) dapat bertindak dalam melakukan pengawasan terhadap kebijakan manajemen dan memberi arahan terhadap manajemen. Berdasarkan definisi yang telah dikemukakan oleh para ahli sebelumnya mengenai dewan komisaris independen, maka dapat disimpulkan bahwa dewan komisaris independen merupakan bagian dari anggota komisaris yang bertugas dalam memberikan pengawasan terhadap kebijakan perusahaan, memberikan saran kepada dewan direksi, serta menyeimbangkan kepentingan antara pemegang saham publik dan pengendali.

Likuditas. Menurut Syamsudin (2011:41) likuiditas merupakan kemampuan dari perusahaan dalam melakukan pembayaran kewajiban finansial yang bersifat jangka pendek pada saat jatuh tempo dengan menggunakan aktiva lancar. Rasio likuiditas adalah rasio yang menggambarkan kemampuan perusahaan dalam memenuhi seluruh kewajibannya atau membayar utang jangka pendeknya.

Dalam melakukan pengukuran likuiditas pada perusahaan, dapat dilakukan dengan membandingkan total aktiva lancar dengan total pasiva lancar atau utang jangka pendek. Menurut Gumanti (2011) rasio likuiditas merupakan rasio yang menunjukkan lancar atau tidaknya suatu perusahaan dalam memenuhi semua kewajiban jangka pendeknya. Rasio tersebut memberikan gambaran mengenai seberapa besar kemampuan perusahaan dalam melakukan pembayaran terhadap semua kewajibannya yang telah jatuh tempo dalam waktu kurang dari satu tahun. Berdasarkan definisi yang telah dikemukakan oleh para ahli sebelumnya mengenai likuiditas maka dapat disimpulkan bahwa likuiditas merupakan ukuran kemampuan dari perusahaan dalam menjalankan kewajibannya untuk menyelesaikan utang yang bersifat jangka pendek yang sudah jatuh tempo.

Kaitan Kepemilikan Manajerial Terhadap Kemungkinan Kebangkrutan. Kepemilikan manajerial merupakan bagian dari tata kelola perusahaan (corporate governance) yang dinilai sangat efektif sebagai sarana dalam memonitoring yang dapat meningkatkan kualitas dari laporan perusahaan menjadi lebih baik (Merkusiwati, 2014). Menurut Fan et al (2013), probabilitas kebangkrutan sangat berhubungan dengan faktor institusional eksternal. Struktur kepemilikan dan kualitas dari pemerintah sangat berpengaruh terhadap keputusan-keputusan atas perusahaan. Perusahaan yang mempunyai struktur kepemilikan dan efektivitas yang lemah dapat menunjukkan bahwa perusahaan tersebut memiliki kinerja dan operasional yang buruk. Berdasarkan pernyataan tersebut Fan et al menyatakan jika lemahnya struktur 
kepemilikan yang ada di dalam perusahaan dapat menjadi salah satu faktor penyebab munculnya kemungkinan kebangkrutan di dalam perusahaan.

Kaitan Proporsi Dewan Komisaris Independen Terhadap Kemungkinan Kebangkrutan. Pada umumnya, perusahaan yang mempunya dewan komisaris independen lebih banyak cenderung akan memiliki tata kelola perusahaan yang baik pula. Hal ini serupa seperti apa yang dikatakan oleh Emrinaldi (2007) bahwa semakin banyak jumlah dewan komisaris independen di dalam sebuah perusahaan maka akan semakin kecil pula potensi terjadinya situasi kesulitan keuangan. Berdasarkan pernyataan tersebut maka diketahui bahwa proporsi dewan komisaris independen dapat mempengaruhi kemungkinan kebangkrutan dalam suatu perusahaan dikarenakan dengan hadirnya dewan komisaris independen, pelaksanaan manajemen dalam perusahaan tentunya akan lebih diawasi sehingga memperkecil kemungkinan kebangkrutan.

Kaitan Likuiditas Terhadap Probabilitas Kebangkrutan. Imam dan Reva (2012) pernah melakukan penelitian dan berkesimpulan bahwa likuiditas tidak memiliki pengaruh yang signifikan terhadap kesulitan keuangan atau probabilitas kebangkrutan. Penelitian Luciana dan Kristijadi (2003), Luciana (2006) dan Novita et al (2014) menyatakan bahwa likuiditas memiliki pengaruh yang signifikan terhadap kesulitan keuangan atau kemungkinan kebangkrutan pada perusahaan. Semakin besar rasio likuiditas maka semakin kecil pula kemungkinan perusahaan mengalami kebangkrutan. Semakin likuid suatu perusahaan maka perusahaan tersebut dapat memenuhi kewajiban jangka pendeknya dengan baik, sehingga risiko keuangan menjadi semakin kecil (Fransica \& Natsir, 2019). Hal ini berarti semakin Likuid suatu perusahaan akan semakin kecil kemungkinan terjadinya kebangkrutan.

Berdasarkan hasil penelitian yang telah dilakukan, maka dapat diketahui jika likuiditas mampu memprediksi kemungkinan kebangkrutan.

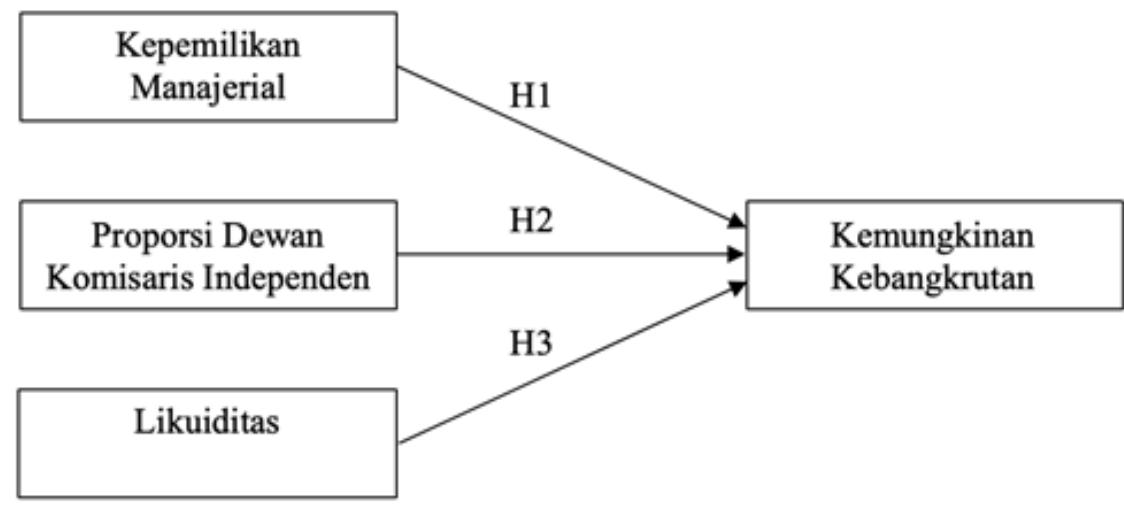

Gambar 1. Model Penelitian

\section{METODOLOGI}

Penelitian ini menggunakan metode penelitian deskriptif. Tujuan dari penelitian deskriptif adalah untuk mendeskripsikan dan menggambarkan secara sistematis, faktual, dan akurat mengenai fakta-fakta, sifat-sifat, serta hubungan antar berbagai fenomena yang sedang diselidiki. Penelitian ini dilakukan untuk menguji dan mencari tahu apakah terdapat pengaruh mekanisme tata kelola perusahaan dan kinerja keuangan terhadap probabilitas kebangkrutan pada perusahaan manufaktur sub sektor makanan dan minuman yang terdaftar di Bursa Efek Indonesia tahun 2014-2018. 
Teknik pemilihan sampel yang digunakan dalam penelitian ini adalah non probability sampling dengan teknik purposive sampling. Teknik purposive sampling merupakan teknik dalam pengambilan sampel yang tidak berdasarkan secara acak, melainkan berdasarkan adanya pertimbangan dan kriteria khusus terlebih dahulu yang berfokus pada suatu tujuan tertentu (Arikunto: 2006).

\section{HASIL UJI STATISTIK}

\section{Hasil Uji Multikolinearitas}

Tabel 1. Hasil Uji Multikolinearitas

\begin{tabular}{|l|l|l|l|}
\hline & LK & KI & KM \\
\hline LK & 1.000000 & -0.130852 & 0.594516 \\
\hline KI & -0.130852 & 1.000000 & -0.214553 \\
\hline KM & 0.594516 & -0.214553 & 1.000000 \\
\hline
\end{tabular}

Berdasarkan tabel di atas dapat dilihat besaran kekuatan korelasi antar variabel bebas. Jika korelasi antar variabel bebas > 0,8 maka dapat diindikasikan adanya multikolinearitas dalam model regresi. Dari hasil data pengujian di atas dapat dilihat bahwa tidak ada korelasi yang memiliki nilai lebih dari 0,8 . Sehingga dapat disimpulkan bahwa variabel kepemilikan manajerial, proporsi dewan komisaris independen, dan likuiditas tidak mengalami multikolinearitas dalam model regresi pada perusahaan manufaktur sektor industri barang konsumsi makanan dan minuman tahun 2014-2018.

\section{Hasil Uji Chow}

Tabel 2. Hasil Uji Chow

\begin{tabular}{llll}
\hline Effects Test & Statistic & d.f. & Prob. \\
\hline Cross-section F & 15.401322 & $(16,14)$ & $\mathbf{0 . 0 0 0 0}$ \\
Cross-section Chi-square & 99.390256 & 16 & 0.0000
\end{tabular}

Dari data hasil pengujian, dapat dilihat nilai probabilitas cross-section $F$ adalah sebesar 0,0000 dan nilai probabilitas cross-section Chi-square adalah sebesar 0,0000 yang lebih kecil dari nilai signifikansi sebesar 0,05. Maka dari itu dapat disimpulkan bahwa H1 diterima dan model regresi yang terpilih melalui uji Chow ini adalah fixed effect model. Tahap selanjutnya adalah melakukan uji Hausman untuk menentukan model mana yang tepat di antara random effect model dan fixed effect model.

\section{Hasil Uji Hausman}

Tabel 3. Hasil Uji Hausman

\begin{tabular}{|c|c|c|}
\hline \multicolumn{3}{|c|}{$\begin{array}{l}\text { Correlated Random Effects - Hausman Test } \\
\text { Equation: Untitled } \\
\text { Test cross-section random effects }\end{array}$} \\
\hline Test Summary & $\begin{array}{l}\text { Chi-Sq. } \\
\text { Statistic }\end{array}$ & Chi-Sq. d.f. Prob. \\
\hline Cross-section random & 2.353028 & 0.3084 \\
\hline
\end{tabular}


Dari data hasil pengujian, dapat dilihat nilai probabilitas dari cross-section random adalah sebesar 0,3084 yang lebih besar dari nilai signifikansi sebesar 0,05. Maka dari itu dapat disimpulkan bahwa $\mathrm{H} 0$ diterima dan model regresi yang terpilih dari uji Hausman ini adalah random effect model. Tahap selanjutnya adalah melakukan uji Lagrange Multiplier untuk menentukan model mana yang tepat di antara common effect model dan random effect model.

\section{Hasil Uji Lagrange Multiplier}

Tabel 4. Hasil Uji Lagrange Multiplier

\begin{tabular}{|c|c|c|c|}
\hline \multicolumn{4}{|c|}{$\begin{array}{l}\text { Lagrange Multiplier Tests for Random Effects } \\
\text { Null hypotheses: No effects } \\
\text { Alternative hypotheses: Two-sided (Breusch-Pagan) and one- } \\
\text { sided }\end{array}$} \\
\hline \multicolumn{4}{|c|}{ Test Hypothesis } \\
\hline Breusch-Pagan & $\begin{array}{l}6.731773 \\
(\mathbf{0 . 0 0 9 5 )}\end{array}$ & $\begin{array}{l}1.054472 \\
(0.3045)\end{array}$ & $\begin{array}{l}7.786245 \\
(0.0053) \\
(<0.05)\end{array}$ \\
\hline
\end{tabular}

Dari data hasil pengujian, dapat dilihat probabilitas dari cross-section Breusch-Pagan adalah sebesar 0,0095 yang lebih kecil dari nilai signifikansi sebesar 0,05. Maka dari itu dapat disimpulkan bahwa $\mathrm{HO}$ ditolak dan model regresi yang terpilih melalui uji Lagrange Multiplier adalah random effect model.

\section{Hasil Uji t}

Tabel 5. Hasil Uji t

\begin{tabular}{lllll}
\hline Variable & \multicolumn{2}{l}{ Coefficient Std. Error } & t-Statistic & Prob. \\
\hline C & -3.933633 & 2.985764 & -1.317463 & 0.1914 \\
KM & -0.952133 & 1.610880 & -0.591064 & 0.5561 \\
KI & 21.91012 & 10.38628 & 2.109524 & 0.0380 \\
LK & 0.278070 & 0.206474 & 1.346759 & 0.1818 \\
\hline
\end{tabular}

Nilai probabilitas variabel kepemilikan manajerial adalah sebesar 0,0561 yang lebih besar dari nilai signifikansi sebesar 0,05, sehingga H0 diterima. Maka dapat disimpulkan bahwa tidak terdapat pengaruh signifikan kepemilikan manajerial terhadap kemungkinan kebangkrutan pada perusahaan manufaktur sektor industri barang konsumsi makanan dan minuman tahun 2014-2018. Nilai probabilitas variabel proporsi dewan komisaris independen adalah sebesar 0,0380 yang lebih kecil dari nilai signifikansi sebesar 0,05, sehingga H0 ditolak. Maka dapat disimpulkan bahwa terdapat pengaruh signifikan proporsi dewan komisaris independen terhadap kemungkinan kebangkrutan pada perusahaan manufaktur sektor industri barang konsumsi makanan dan minuman tahun 2014-2018. Nilai probabilitas variabel proporsi dewan komisaris independen adalah sebesar 0,1818 yang lebih besar dari nilai signifikansi sebesar 0,05 , sehingga $\mathrm{H0}$ diterima. Maka dapat disimpulkan bahwa tidak terdapat pengaruh signifikan likuiditas terhadap kemungkinan kebangkrutan pada perusahaan manufaktur sektor industri barang konsumsi makanan dan minuman tahun 2014-2018. 
Hasil Uji Koefisien Determinasi $\left(\mathbf{R}^{2}\right)$

Tabel 6. Hasil Uji Koefisien Determinasi $\left(\mathrm{R}^{2}\right)$

\begin{tabular}{llll}
\hline R-squared & 0.048576 & Mean dependent var & 1.235527 \\
Adjusted R-squared & $\mathbf{0 . 1 3 3 3 8 0}$ & S.D. dependent var & 2.164132 \\
S.E. of regression & 2.149651 & Sum squared resid & 374.3010 \\
F-statistic & 1.378519 & Durbin-Watson stat & 1.820078 \\
Prob(F-statistic) & 0.255257 & & \\
\hline Unweighted Statistics & & & \\
\hline R-squared & 0.172378 & Mean dependent var & 5.063125 \\
Sum squared resid & 1451.127 & Durbin-Watson stat & 0.474398 \\
\hline
\end{tabular}

Berdasarkan hasil estimasi di atas dapat dilihat nilai Adjusted $R$-squared adalah sebesar 0,133380. Hal ini dapat diartikan bahwa kemungkinan kebangkrutan dapat dijelaskan oleh variabel kepemilikan manajerial, proporsi dewan komisaris independen, dan likuiditas sebesar $13,34 \%$ sedangkan sisanya sebesar $86,66 \%$ dapat dijelaskan oleh variabel lainnya yang berasal dari luar variabel independen yang diteliti.

\section{Penutup}

Berdasarkan hasil analisis yang telah dilakukan dan dibahas oleh peneliti tentang pengaruh mekanisme tata kelola perusahaan dan kinerja keuangan terhadap kemungkinan kebangkrutan pada perusahaan manufaktur sektor industri barang konsumsi yang terdaftar di Bursa Efek Indonesia, maka dihasilkan kesimpulan sebagai berikut:

1. Penelitian menyatakan bahwa kepemilikan manajerial tidak berpengaruh secara signifikan terhadap kemungkinan kebangkrutan pada perusahaan manufaktur sub sektor konsumsi makanan dan minuman tahun 2014-2018.

2. Penelitian menyatakan bahwa terdapat pengaruh positif yang signifikan proporsi dewan komisaris independen terhadap kemungkinan kebangkrutan pada perusahaan manufaktur sub sektor makanan dan minuman tahun 2014-2018. Hal ini berarti jika proporsi dewan komisaris independen (X2) meningkat maka akan menaikkan nilai probabilitas kebangkrutan dari sebuah perusahaan.

3. Penelitian menyatakan bahwa likuiditas tidak berpengaruh secara signifikan terhadap kemungkinan kebangkrutan pada perusahaan manufaktur sub sektor makanan dan minuman tahun 2014-2018.

\section{DAFTAR PUSTAKA}

Agoes, Sukrisno dan I Cenik Ardana. 2014. Etika Bisnis dan Profesi. Jakarta: Salemba Empat.

Agoes, Sukrisno dan I Cenik Ardana.2014."Etika Bisnis dan Profesi Tantangan Membangun Manusia Seutuhnya Edisi Revisi”. Jakarta: Salemba Empat

Arikunto, S. 2006. Metode Penelitian Kualitatif. Jakarta: Bumi Aksara.

Emiraldi, Nur DP. 2007. Analisis Pengaruh Tata Kelola Perusahaan (Corporate Governance) terhadap Kesulitan Keuangan Perusahaan (Financial Distress): Suatu Kajian Empiris. Jurnal Akuntansi dan Bisnis, Vol.9, No.1, h. 88-108.

Fransica, \& Natsir, K. (2019). Pengaruh Profitabilitas, Likuiditas dan Ukuran Perusahaan terhadap Keputusan Lindung Nilai. Jurnal Manajerial Dan Kewirausahaan, 7(3), 
$462-461$.

Gumanti, Tatang Ary. 2011. Manajemen Investasi Konsep, Teori dan Aplikasi. Jakarta: Mitra Wacana Media.

Imam Mas'ud dan Reva Maymi. 2012. Analisis Rasio Keuangan untuk Memprediksi Kondisi Fanancial Distress Perusahaan Manufaktur yang Terdaftar di Bursa Efek Indonesia. Jurnal Akuntansi Universitas Jember. Vol. 10. No. 2.

Luciana Spica Almilia dan Kristijadi. 2003. Analisis Rasio Keuangan untuk Memprediksi Kondisi Financial Distress Perusahaan Manufaktur yang Terdaftar di BEJ. Jurnal dan Akuntansi Auditing Indonesia. vol. 7 No. 2.

Lukman Syamsuddin. 2004. Manajemen Keuangan Perusahaan. Jakarta : PT Raja Grafindo.

Putri, dan Merkusiwati, Ni. kt. L. (2014). Pengaruh Mekanisme Corporate Governance, Likuiditas, Leverage, dan Ukuran Perusahaan pada Financial Distress. E-Jurnal Akuntansi.Vol. 1, No. 7, Halaman 93-106.

Ramadhani, Ayu Suci, dan Lukviarman, Niki. 2009. Perbandingan Analisis Prediksi Kebangkrutan Menggunakan Model Altman Pertama, Altman Revisi, Dan Altman Modifikasi Dengan Ukuran Dan Umur Sebagai Variabel Penjelas. Jurnal Siasat Bisnis Vol. 13 No. 1April 2009: 15-28.

Tjeleni, Indra E. 2013. "Kepemilikan Manajerial dan Institusional Pengaruhnya Terhadap Kebijakan Hutang Pada Perusahaan Manufaktur Di Bursa Efek Indonesia”. Jurnal EMBA.Vol.1, No.3 hal 129 - 139.

Ujiyantho, A dan Pramuka, B. S.. 2007. Mekanisme Corporate Governance, Manajemen Laba Dan Kinerja Keuangan.Prosiding, Simposium Nasional Akuntansi X, Juli 2007, Makassar.

Wahidahwati. 2002. "Pengaruh Kepemilikan Manajerial dan Kepemilikan Institusional terhadap Kebijakan Hutang Perusahaan". Simposium Nasional Akuntansi IV IAI. 1084-1107.

Yuli Soesetio. (2007). Kepemilikan Manajerial Dan Institusional, Kebijakan Dividen, Ukuran Perusahaan, Struktur Aktiva Dan Profitabilitas Terhadap Kebijakan hutang. Jurnal Bisnis Dan Akuntansi Vol 11 No. 3 https://jom.unri.ac.id diakses 10 juli 2017 